\title{
Atipik Prezente Kist Hidatik: Pankreas Başında Kitle
}

\section{Atypically Presented Cyst Hydatid: Mass At The Head Of Pancreas}

\author{
'Erzıncan Üniversitesi Genel Cerrahi A:D. \\ ${ }^{2}$ Erzıncan Üniversitesi Radyoloji A:D. \\ Yazıșma Adresi / Correspondence: \\ Arda Işık \\ Erzıncan Universitesi Tıp Fakültesi, Genel Cerrahi A:D., ERZiNCAN \\ T: +90 4462261818 E-mail: kararda@yahoo.com
}

Arda Işık', Deniz Fırat', Serdar Korkmaz², İsmail Demiryılmaz', İsmayil Yılmaz'

Geliş Tarihi / Received : 08.01.2018 Kabul Tarihi / Accepted : 02.03.2018

\begin{abstract}
Öz
Echinococcus granulosus, ülkemizde sık görülen, genellikle karaciğerde gözlenen, paraziter bir hastalkktr. 20 yaşında erkek hasta, sağ ana hepatik kanala açilmış ve buna sekonder pankreas baş̧nda koledok dilatasyonuna sebep olan kist hidatik olgusu ile prezente edildi. Kolesistektomi, unroofing ve kist eksizyonu yaplan hasta postoperatif 3. gün taburcu edildi. Kontrol abdominal bilgisayarlı tomografi incelemesinde dilate koledok görüntüsü kaybolan hastanın takiplerinde herhangi bir sorun ile karşllaşlıadı. Kist hidatik, evresine göre tedavisi perkütan drenaj veya cerrahi olarak uygulanan, nadirde olsa safra kanallarına açlan ve buna sekonder kolanjit ve pankreas başınnda kitle ile klinik bulgu verebilen bir hastalkktr. Antijen ve antikor seviyeleri tanı için yardımcı olabilir. Kistin karakteristik özellikleri görüntüleme yöntemleri ile tanımlanarak, tedavi planı her hastaya özel planlanmalıdır. ( Sakarya Tıp Dergisi 2018, 8(1):149-152
\end{abstract}

Olgu sunumumuz 2015 HPB Cerrahi Kongresinde sunulmuştur.

Anahtar karaciğer kist hidatik; dilate koledok; pankreas başında kitle

Kelimeler

\section{Abstract}

Amaç Echinococcus granulosus, which is often observed in the liver, is a common parasitic disease in our country. Twenty-year-old male patient with cyst hydatid presented in this case. Cyst hydatid opened to right hepatic duct. By this it dilated common bile duct at the head of the pancreas. Cholecystectomy, unroofing and cystectomy were done. Patient was discharged on third postoperative day. At follow up, the image of dilated common bile duct at computerized tomography was disappeared. Patient did not encounter any problems. The treatment choice of hydatid cyst as percutaneous drainage or surgical depends according to the stage. Though it rarely opens to bile ducts, may cause cholangitis and finally could misdiagnosed as mass at pancreas head. Antigen and antibody levels can help to diagnose. By defining the characteristics of cyst with imaging studies, treatment can be planned specific to each patient. ( Sakarya Med J, 2018, 8(1):149-152 ).

Keywords: liver cyst hydatid; dilated choledoch; mass at the pancreas head 


\section{Giriş}

Echinococcus granulosus, dünyada sık görülen, genellikle karaciğerde gözlenen, paraziter bir hastalıktır ${ }^{1}$. Hidatik kistler her ne kadar en çok karaciğer ve akciğerde gözlense de hemen hemen her organda ve sistemde gelişebilir. Bu hastalı̆ın beklenmeyen bir yerleşimde gözlenmesi durumunda tanısal ve terapötik problemlere neden olması kaçınıımazdır. Çeşitli organlarda gözlenmesi ve klinik açıdan herhangi bir yumuşak doku tümörünü taklit etmesi beklenebilir. Yerleştiği organ itibariyle, komşu organ patolojileriyle karışabilir. Burada safra yoluna açlan kist hidatiğe sekonder gelişen pankreas başında kitle imajı veren hidatik kist olgusu prezente edildi.

\section{Olgu Sunumu:}

20 yaşında erkek hasta kliniğimize karın ağıısı şikayeti ile başvurdu. Yaklaşık 1 yıldır bu şikayetlerinin zaman zaman tekrarladığını ifade eden hastanın hikayesin de bir özellik saptanmadı. Fizik muayenede sağ üst kadranda palpasyon ile hassasiyet dışında bir özellik yoktu. Yapılan batın ultrasonografisinde kolelitiazis, dilate koledok ve karaciğerde evre 3 kist hidatik ile uyumlu septalı sivı koleksiyonu izlendi. İndirekt hemaglütinasyon testi titrede 1/80, normal olarak tespit edildi. Tomografi görüntülemesinde, sağ ana hepatik kanala açılmış (şekil 1a) ve koledok içi basıncı artırarak pankreas başında koledok dilatasyonuna (şekil 1b) sebep olan, multiseptalı evre 3 kist hidatik tespit edildi. Total bilirubin değerleri normal, gamaglutamil transferaz(GGT) değeri 220-300 $\mathrm{U} / \mathrm{L}$ arası olarak yüksek, amilaz-lipaz değerleri normal gözlendi. Asendan kolanjit riski nedeniyle, preoperatif endoskopik retrogradkolanjiografi (ERCP) uygulanmadı. Operasyonda kolesistektomi, unroofing ve total kist eksizyonu yapıldı. Kist içine antiskolosidal madde olarak hipertonik salin uyguland. Hasta postoperatif 3 . gün albendazol $15 \mathrm{mg} / \mathrm{kg} /$ gün ile taburcu edildi. Postoperatif 1 . ay kontrol bilgisayarlı tomografileri (BT) incelemelerinde dilate koledok görüntüsü kaybolan hastanın takiplerinde herhangi bir sorun ile karşılaşılmadı. Çalışma için hasta onamı alınmıştır.

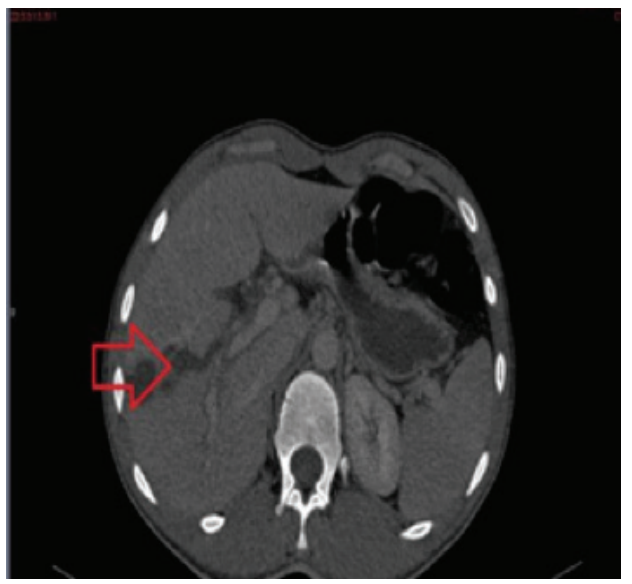

Şekil 1a: Multiseptalı evre 3 kist hidatik bilgisayarlı tomografi görüntüsü

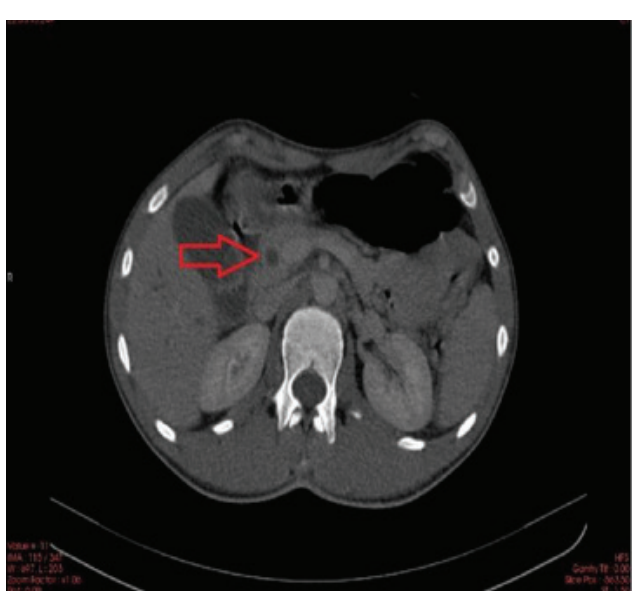

Şekil 1b: Pankreas başında koledok dilatasyonuna sebep olan kist hidatik bilgisayarlı tomografi görüntüsü

\section{Tartışma:}

Hidatidozis dünyanın bazı bölgelerinde özellikle Afrika ve Güney Asyada önemli bir halk sağlığı problemidir. Her ne kadar eğitim ve kontrol programları nedeniyle hidatidozis insidansında düşüş gözlense de hala ülkemizde bazı yerleşimlerde özellikle Doğu Anadolu ve Güneydoğu Anadolu bölgesinde sık gözlenmektedir. Nadirde olsa safra kanallarına açılan ve buna sekonder kolanjit ve pankreas başında kitle ile klinik bulgu verebilir. Evresine göre tedavisi perkütan drenaj veya cerrahi 
olarak uygulanabilir ${ }^{2-5}$.

Karaciğer dışı yerleşimde hidatidosis- ekinokokkosis tanısının preoperatif konulması çoğu zaman oldukça zordur. Yumuşak doku tümörü, abse, sinovyal kist ve malign tümör ayıгıcı tanıda düşünülmelidir. Bizim vakamızda da pankreas başında kitle olarak gözlenmiş ve bu nedenle ayıııcı tanı olarak güçlük arz etmiş̧ir. Biyopsi öncesinde kistden içerik kaçağı ve anaflaksi riskine karşın mutlaka kist hidatik tanısı konfirme edilmelidir. Lokalizasyon olarak pankreas çok nadir olarak gözlenir. Literatürde bu konuyla ilgili vaka takdimleri mevcuttur6. Bu nedenle pankreas başı kanseri, pankreasın kistik neoplazmları ve pankreatolitiasis gibi pankreas yerleşimli diğer patolojiler ayırıcı tanıda önemlidir. Kist hidatik tedavisin de, antijen ve antikor seviyeleri tanı için yardımcı olabilir.

Evresine göre perkütan drenaj veya cerrahi ile tedavi edilebilir. Medikal tedavi kist hidatik tedavisinde tek başına kullanılmayan, ancak diğer tedavi seçeneklerine eklenebilen bir tedavi yöntemidir. Komplike vakalar dahil cerrahi tedavi ile \%95 kür elde edilebilir. Evre 1-4 kist hidatik tedavisinde temel tedavi cerrahidir. Cerrahiyi red eden, cerrahi riski yüksek olan, evre 1 kist hidatik vakalarında perkütan drenaj denenebilir. Ancak perkütan aspirasyon,injeksiyon, repair( PAIR) Tip I,II ve bazı seçilmiş Tip III kist hidatik vakalarında uygulanabilmektedir. Preoperatif fistül şüphesinde ERCP ile basınç düşürmesi sonrası safra yolları için cerrahi işlem uygulanabilir. Evre 5 kist hidatikte temel tedavi küratif amaçlı olmayan, semptoma yönelik medikal tedavidir ${ }^{7}$

\section{Sonuç:}

Atipik prezente kist hidatiğin karakteristik özellikleri görüntüleme yöntemleri ile tanımlanarak, tedavi planı her hastaya özel planlanmalıdır. 
1. Davarci I, Tuzcu K, Karcioglu M, Yetim I, Aydogan A, Turhanoğlu S. Ana esthetic Management of Anaphylactic Shock Caused by Nonruptured Hydatid Cyst of the Liver.West Indian Med J. 2014: 11;63.

2. Sayek I, Tırnaksız MB, Doğan R. Cystic Hydatid Disease: Current trends in diagnosis and management. Surg Today, 2004;34:987-96.

3. Mousavi SR, Samsami M, Fallah M, Zirakzadeh H. A retrospective survey of human hydatidosis based on hospital records during the period of 10 years. J Parasitic Dis. 2012; 36: 7- 9.

4. Vicidomini S, Cancrini G, Gabrielli S, Naspetti R, Bartoloni A. Muscular cystic hydatidosis: Case report. BMC Infect Dis. 2007; 7: 23.

Sakarya TIp Dergisi 2018;8(1):149-152

bone. J Res Med Sci. 2005; 10: 101- 104.

6. Akbulut S, Yavuz R, Sogutcu N, Kaya B, Hatipoglu S, Senol A, Demircan F. Hydatid cyst of the pancreas: Report of an undiagnosed case of pancreatic hydatid cyst and brief literature review. World J Gastrointest Surg. 2014;6:190-200.

7. Yetim I, Erzurumlu K. Karaciğer Hidatik Kistleri Tedavisinde Güncel Yaklașımlar. J Clin Anal Med 2013;4: 64-71 